\title{
Dealing with Self-Interest Amongst Non-Executive Directors
}

by David Gibbs

No director should operate from self-interest whether executive or non-executive. Here, David Gibbs, Lecturer in Company and Commercial Law at the University of Hertfordshire School of Law in the UK, uses the issue of non-executive directors holding multiple positions simultaneously to open our eyes to the legal and other complexities involved.

The literature on director self-interest in the corporate sector is predominately focused on how the risk of executive management self-interest can be reduced. Seldom is the focus on the non-executive, who is theoretically and practically required to take on an increasing role on a corporate board to improve governance. Without sufficient understanding of the controls on their self-interest the increased involvement may not have the desired outcome. The research described in this article, aimed to examine the legal controls and governance incentives on nonexecutive self-interest to determine if they are suitable in aligning the interests of the non-executives with the company.

To conduct this study, multiple directorships were used as a proxy for self-interest. An assumption was made that if non-executives were properly deterred and incentivised, appointing more non-executives could benefit the company. Conversely it was assumed that failure to have sufficient controls could mean that more non-executives would simply represent more people reaping the rewards of such positions for their own benefit at the company's expense (sometimes referred to as "perquisite consumption").

To analyse this, a review of the legal controls and enforcement of them was conducted. The analysis looked at the non-executive's fiduciary duty of loyalty to the company as well as potential enforcement of that duty through the statutory derivative claim in the Companies Act 2006, Part 11. The analysis then continued in to a theoretical and quantitative empirical analysis on governance controls. The former analyses covered key governance theories: agency, stewardship and resource dependence theory. The latter identified possible governance controls, such as remuneration and measured them against the amount of multiple appointments held in a company by non-executives with the aim of identifying whether there are any suitable governance controls (such as remuneration or equity 
payments) that could reduce the risk of non-executive self-interest. It was also hoped to find evidence on whether multiple appointments are a form of self-interest.

\section{Legal Controls}

When an individual takes responsibility for another's interests that responsibility requires the supervision of equity (P Finn, Fiduciary Obligations (Law Book Company, 1977) unless specifically circumscribed by contract (Kelly v Cooper [1993] AC 205). The company has separate legal personality from its members and controllers but that personality is defective, as it does not have the capability to act without those controllers. The board of directors are the controllers and they are taking responsibility for the interests of the company. Legal controls are known as "fiduciary" controls and, as fiduciaries, directors must be loyal to the interests of the company. Loyalty is an onerous duty, as it requires the suspension of self-interest.

The judiciary has doubted whether the duty of loyalty would deter board members from pursuing their own self-interest through the taking of multiple roles. The example in Cambridge v Makin [2011] EWHC 12 highlighted that non-executives are not necessarily prevented from taking up a competing roles. However, the fact remains that that the non-executive is a fiduciary and must remove self-interest from the performance of their function. In short, where the competing role conflicts with the duty of loyalty owed to the company then it will be a breach of fiduciary duty.

The legal concept of equity, or fairness, allows for fiduciaries to defend themselves against accusations of conflict of interest, on the grounds that fulfilling their fiduciary duty requires them to hold competing roles. An example of this would be estate agents. Whilst not tested by the courts, it is doubted such a defence would be available to non-executives, as they do not need to hold multiple roles to fulfil their responsibility. However, it is clear that, in any case, fiduciary duty is only breached if any competing role conflicts with the duty of loyalty owed to the company. The issue then is when does a competing role conflicts with the duty.

The use of words such as "competing" in discussing conflict of interest are in fact a problem in company law because they beg questions about what the interests of the company are. To explain, a company is capable of doing anything that is not illegal. Therefore, some analyses have determined that a director is a "general fiduciary" 
with "unlimited" fiduciary capacity (Re Allied Business \& Financial Consultants [2011] EWCA Civ 751). This would mean that directors' duty of loyalty could not be said to be limited to any particular interest since a company's constitution is open to any business. Others have argued that the duty of loyalty should be circumscribed by determining whether the personal interest can be said to be competing with the interests of the company (JD Wetherspoons $v$ Van de Berg \& Co [2009] EWHC 639) or falls within the company's scope of business (S Worthington, 'Fiduciary Duties and Proprietary Remedies' Cambridge Law Journal (2013) 720; D Kershaw, 'Does it matter how the law thinks about corporate opportunities' Legal Studies (2005 25(4)) 533). All these tests would require an analysis of what the interests of the company are to identify a breach of duty but the question remains - if you have a fiduciary role because of a duty of loyalty - what are those interests you must be loyal to?

However the question of which interests of the company require loyalty can be resolved by remembering three key orthodox fiduciary principles:

1) that the duty of loyalty is "strict" (which in legal terms means that persons can be held legally responsible for the damage and loss caused by its breach without any requirement to prove fault, negligence or intention);

2) that a breach is based on a conflict between duty and interest; and

3) the onus is on the fiduciary to show there was no conflict.

It is the second principle that gives most guidance. The duty of loyalty itself is designed to reduce the risk that self-interest may result in an individual not performing their responsibility to the best of their ability so as to take the interest personally. Yet, where there is no responsibility there can be no duty. Requiring someone to be loyal where they have not taken responsibility would be unfair. Therefore, it is possible for a non-executive to take on a competing role against the company's interests provided those interests were not something the non-executive took responsibility for.

Two things a non-executive should keep in mind though. First is that the duty is flexible. It will attach itself to any responsibility. Therefore, if a non-executive uses their access to unilaterally take responsibility for the interests of one of the two 
competing companies they duty will attach itself to that responsibility (Bolkiha $v$ KPMG [1999] 2 AC 222). Secondly, it is the non-executive's task to assess what their responsibility is to the company to determine when they can and cannot act with selfinterest in multiple roles. Given the widely varying degree of responsibility any nonexecutive may have this would be a personal task. However, generally the role of the non-executive has expanded from supervision to increased involvement in strategy. The fiduciary duty will follow that increased responsibility and a non-executive should monitor their responsibility regularly to avoid any unwanted conflicts.

\section{Enforcement}

From the literature review conducted as part of my research, it can be concluded that current legal controls are suitable for controlling non-executive self-interest since any self-interest in the performance of their functions is regulated by the duty of loyalty. However, effective law needs effective enforcement to ensure proper governance. As Zhang ( $Z$ Zhang 'Legal Deterrence: the foundation of corporate governance evidence from China' Corporate Governance: An International Review (2007, 15(5)) 741 ) showed, whilst companies may remove the board (in the UK by a $50 \%$ shareholder resolution under the Companies Act 20016, s 168), if enforcement is not effective it can result in bad governance. And the fact is that private enforcement of duties against directors is rare and seldom is that enforcement against nonexecutives. The new statutory derivative claim, under the Companies Act 2006, part 11, was designed, according to the Law Commission, to allow more meritorious claims to proceed and not be hindered by the legal technicalities that blighted the common law claim.

This new claim allows a shareholder to enforce a right of action vested in the company in respect of a breach of duty by a director. The evidence to date shows that whilst claims are more likely to be successful it is still unlikely that a claim could be brought against a non-executive based on the criteria used by the courts in applying the procedure and its discretion under the new claim. So far $33 \%$ of claims brought have been successful. A deeper analysis of these cases show the success is largely based on strong legal merits to the claim, which may be difficult in proving a claim against non-executives, and the failure of the defendant to produce a reason to dismiss the claim, again unlikely for a non-executive. For example, in Stainer $v$ Lee on the evidence available there has clearly been fraud and in Kiani $v$ Cooper the defendant failed to produce any evidence to refute the claims. However, other cases 
have shown that weak legal claims and other reasons to dismiss mean a case will not be successful. A case brought against a non-executive may struggle to satisfy the court that there is no good reason to dismiss since it will most likely question why the majority controllers of the company have not chosen to enforce the duty. However, given that the claim is not blighted by technicalities and is a matter of discretion it is at least possible a claim could be brought against a non-executive.

\section{Governance Theories}

In my research, three governance theories were selected to identify how a nonexecutive might be incentivised when choosing to take, and acting in, multiple roles. Agency and stewardship theory both see the individual as "a utility maximiser" someone who considers actions, computes their consequences and then rates their usefulness and ensures requisite implementation in a way that maximises the individual's own utility. However, agency theory sees the individual's utility in monetary terms whereas a steward's utility is focused more on trust and bonding with a concept such as the company. Alternatively resource dependence theory is not concerned with utility maximisation but with the ability of the individual to do the job. For those operating under resource dependence theory, it could be considered that an individual with more appointments will do a better job as they have more value in the managerial labour market. Therefore whether a non-executive takes additional appointments for the company's or personal interests depends on the individual's utility and ability

Existing research that tries to identify suitable theories for good governance such as whether board composition should emphasize independent directors or directors with relevant specialisms, often fails to find any consistent results. Approaching governance based on agency theory may be of little use where directors do not have the experience and a resource dependence approach may be no good where directors playing managerial roles are not properly incentivised. I would also like to highlight the danger of governance converging into a tick-box exercise that complies with the UK Corporate Governance Code. Evidence from Grant Thornton's 2013 Corporate Governance Review (http://www.grantthornton.co.uk/Publications/2013/FTSE-350-Corporate-Governance-Review-2013/ ) shows an increasing adoption of the Code, which is predominately based on agency theory. This should be a concern since governance should be about the removing the risk of self-interest and not about creating the appearance of its removal. 


\section{Empirical Evidence}

From the governance analysis and looking at the theories, hypotheses were formed to determine possible controls on non-executive self-interest and offer evidence as to whether more non-executives could merely mean more people reaping the rewards of such positions for their own benefit at the company's expense. An initial analysis of 30 FTSE 100 companies was then conducted company level over a five-year period (2006-2010) of 30 FTSE 100 companies.

Descriptive statistics have shown a reduction in the range of the maximum and minimum amount of additional appointments held by non-executives in this period suggesting that non-executives are holding fewer multiple appointments. At the same time, fees paid to non-executives on average had increased by $£ 100,000$. A correlation and multiple regression analysis was conducted to predict multiple appointments. Amongst the hypotheses formed it was predicted that where remuneration was higher non-executives would hold more appointments whereas they would hold less where equity (ownership stake) was higher. It was also predicted that where a company had more agency problems (in the form of board meetings held; board meetings missed; CEO-Chair duality; Independent director to executive ratio; Executive equity ownership; board size; ratio of long term incentives to fixed remuneration; executive multiple appointments; remuneration committee meetings) there would be fewer additional appointments.

For remuneration and equity a positive and negative relationship was found for each respectively, as predicted. It suggests that whilst higher remuneration may result in more appointments being taken and thus the possibility of more people reaping the rewards of such positions for their own benefit at the company's expense, whilst equity may serve as a check on additional appointments. However, this must be qualified with the finding of a positive relationship between equity and agency problems in the correlation matrix. Therefore, equity may not be useful in reducing self-interest. This finding is further supported in the regression analysis when conducting a time-series analysis over the five years. Between 2006-2008 equity had a bigger influence (27\%) on reducing multiple appointments than remuneration (16\%) did on increasing them. However, after 2008 that influence of equity was reduced to only $9 \%$ whereas the influence of remuneration was at $11 \%$. 
Analysing agency problems also highlighted the current inadequacies in governance controls on deterring self-interest. The evidence from the research showed that the more agency problems any company had, the more multiple appointments were taken. Thus this research disproved the hypothesis and offered more evidence to suggest that additional appointments, if unchecked, are a form of perquisite consumption. Therefore, the evidence produced from the empirical study suggests regulation may be the only option left to suitably control self-interest since disclosure is already at $100 \%$ in the UK.

Dr. David Gibbs can be contacted at d.gibbs2@herts.ac.uk. His blogspot is www.gibbslawandlife.blogspot.com. 